\title{
Civil law aspects of territorial public self-government activity during the economy's digitalization
}

\author{
Sergei Sharonov ${ }^{1}$, and Nikolai Korovin ${ }^{2 *}$ \\ ${ }^{1}$ Moscow University of the Ministry of Internal Affairs of Russia, 117437, 12, Akademika Volgina str., Moscow, Russian Federation, \\ Sharonov345@mail.ru \\ ${ }^{2}$ Department of Business Law, Arbitration and Civil proceedings, Volgograd State University, 400062, 100, Universitetsky ave., \\ Volgograd, Russian Federation, Nikolay.vlz79@gmail.com
}

\begin{abstract}
The article deals with civil law aspects of territorial public self-government (hereinafter - TPSG) in terms of economy's digitization. The authors show the private law specificity of territorial public selfgovernment, give the classification and characterize civil aspects of activity of bodies of territorial public self-government. The problems of the work of the structures of territorial public self-government in the indicated conditions are identified and the amendments to regulatory legal acts are suggested that contribute to the solution of the mentioned problems.
\end{abstract}

\section{Introduction}

Chapter 8 of the Constitution of the Russian Federation is devoted to local self-government, in turn the bodies of territorial public self-government are a constituent part of national self-government. According to Article 27 of the Federal Law issued on October 6, 2003 No. 131-FZ "On General Principles of Local Self-Government in the Russian Federation" (hereinafter referred to as the Federal Law issued on October 6, 2003 No. 131-FZ), bodies of territorial public self-government appearing by means of self-organization of citizens for the implementation of their own initiatives concerning local issues at their place of residence in a certain territory. According to Article 27 Paragraph 2.5 of the mentioned Law and Article 50 paragraph 2.3 of the Civil Code of the Russian Federation, territorial public selfgovernment can be registered as a legal entity, in particular as a non-profit organization, namely as a public organization (hereinafter - a structure of TPSG).

The structure of territorial public self-government has the right to work for the satisfaction social and domestic needs of citizens, including the actions connected with the improvement of the corresponding territory. As a legal entity, the body of territorial public self-government (TPSG) can enter into legal relations with other participants of civil law contracts, acting as a buyer of goods, a customer in service sector, etc. A number of scientific publications are devoted to the research of territorial public self-government (TPSG), but insufficient attention has been paid to the analysis of civil law aspects of territorial public self-government (TPSG).

The relevance of the topic is also due to the acceleration of digital transformation of the real sector of the economy [1]. Currently, in accordance with the national program "Digital Economy of the Russian Federation", approved by the minutes of the meeting of the Presidium of the Council for Strategic Development and National Projects under the President of the Russian Federation No. 7 issued on June 4, 2019, a number of tasks are being implemented, including the task of introduction of civil law transactions by means of use of digital technologies.

As a result of the implementation of this program, amendments were passed to the civil legislation in terms of supplements to the list of civil rights objects with digital rights objects [2]. The national program contributes to the creation of a stable and secure information and telecommunication infrastructure for high-speed transmission, processing and storage of large amounts of data, accessible to all organizations.

The tools of such infrastructure available for the organization of bodies of territorial public selfgovernment (TPSG require a detailed analysis) in the current scientific, technical and legal realities.

\section{Problem Statement}

The implementation of the national program "Digital Economy of the Russian Federation" is realized by means of the introduction and improvement of digital services and information systems, for example, such as: "Common web site of state and municipal services", Information system " My Mediator ", etc. The establishment of bodies of territorial public selfgovernment along with legal entities of various organizational and legal forms has the opportunity of using digital services. At the same time, there is specificity of legal regulation of the establishment and further activities of such a legal entity as body of

\footnotetext{
*Corresponding author: Nikolay.vlz79@gmail.com
} 
territorial public self-government due to its heterogeneous legal nature. In the conditions of rapidly developing digital technologies, there is a need for their application at all stages of the functioning of bodies of territorial public self-government, including the moment of actions aimed at the registration of such a legal entity.

The analysis of existing legislation and the need for the use of digital technologies in the context of the research topic allows us speaking about the existence of unresolved problems that hinder the achievement of the goals of the national project. The government should ensure the acceleration of changes in legislation, taking into account scientific and technical progress [3]. The right to use available digital technologies by bodies of territorial public self-government, taking into account the specificity of the implementation of their work, should be reflected in the relevant regulatory legal acts.

\section{Research Questions}

In the study of civil law aspects of the activity of structures of territorial public self-government during the digitalization of the economy, it is necessary to take into account their legal nature and the peculiarities of legal regulation of the relations arising from this activity, since such relations are governed by the norms of both private and public law.

\section{Purpose of the Study}

The purpose of the article is the identification of the private law nature of territorial public self-government. In the context of this goal, it is necessary to solve the following tasks. First, it is necessary to identify the civil law aspects of the work of territorial public selfgovernment. Second, it is indispensible to classify the identified aspects. Thirdly, it is needed to characterize these aspects. Fourthly, it is necessary to show the impact of digitalization of the economy on the activity of bodies of territorial public self-government which is being analyzed, to identify problems of legal regulation and solve them.

In order to solve the first and the following tasks, let us use the accumulated knowledge and experience in the area under analysis, and we mean here the theses of scientists and scientific publications. In the scientific community, the concept is quite widespread, according to which the territorial public self-government, registered as a legal entity, has a dual nature, while the legal capacity of territorial public self-government can be realized through municipal and civil legal relations. According to E.G. Komissarova the definition of the legal nature allows us giving legal description of a legal phenomenon and identifying its "legal essence" [4].

S. V. Malyugin in his article devoted to the study of the category of "legal nature", expresses the opinion that in law enforcement activity this category is applicable "to the actual and legal composition of legal relationship", and in scientific activity it reflects "the essential features of various legal phenomena", allows "to understand their place and value in the legal field "[5].

A. V. Fedotov connects an approach based on the constitutional rights of citizens (the right to assemble and conduct meetings at the place of residence and the right to association) with the understanding of the nature of territorial public self-government, and the defines territorial public self-government as a form of legal support for the implementation of these rights. The scientist connects the nature of public interest with the expression of the will of the majority of citizens living in the territory [6].

E. V. Razdyakonova in her article devoted the legal status of territorial public self-government, mentions that "the disclosure of the legal nature of territorial public self-government as a key element that is simultaneously included into the system of public and private law, predetermines the inadmissibility of the exclusive assignment of territorial public self-government to one of them" [7]. According to A. A. Larichev the establishment of structures of territorial public selfgovernment as an element of self-government and the registration of the bodies of territorial public selfgovernment as a legal entity "are the phenomena of different legal nature"[8].

O. I. Bazhenova notes that the public-law nature of territorial public self-government (the resulting organization and management features, the scope and content of rights and obligations) should be taken into account in the development and adoption of decisions by the bodies of territorial public self-government affecting civil law transactions. The author criticizes the civil approach to the category of a legal entity (body of territorial public self-government) and believes that it does not ensure the autonomy of civil law [9]. When revealing the legal nature of territorial public selfgovernment, the scientist notes that territorial public selfgovernment "is an element of the local self-government system" and is based on "territorial principles." According to the author, the main principles and content of the competence of territorial public self-government (including TPSG bodies) are predetermined by its legal nature [10].

In turn, in the context of the goal set in the article, the author finds it necessary to analyze the establishment of territorial public self-government in terms of civil law. The author identifies the private legal nature of territorial public self-government by means of the examination of the essential characteristics of this legal phenomenon and its correlation with civil law.

In the absence of the need to have any economic activity, the body of territorial public self-government can be registered (established from the moment of the registration of the Charter) by local governments as one of the elements of the local government system and not to have the status of a legal entity [11]. These bodies of territorial public self-government have the status of a subject of municipal legal relations and on their own behalf cannot work for the improvement of the territory, other economic activities are meant to meet the social and domestic needs of citizens living in the relevant territory. E. A. Bratseva in her research on territorial 
public self-government notes that bodies of territorial public self-government without the rights of a legal entity cannot participate in civil legal relations and cannot be considered as their subject [12]. K.M. Khudoley and D.M. Khudoley note that in contrast to the territorial public self-government without the registration of a legal entity, the establishment of a body territorial public self-government gives a higher volume capacity, as the latter is has the right to have economic activity [13].

Within the mentioned purpose of the article, it is the territorial public self-government registered as a legal entity that we are interested in from the scientific point of view. Judging from the analysis of the works in the field of territorial public self-government, it can be concluded that the need for the possession of a sufficient amount of legal capacity to satisfy all interests (including social and other interests) determines the establishment of a body of territorial public self-government. From the moment of state registration, the body of territorial public self-government acquires the legal capacity of a legal entity and in accordance with Article 2 Paragraph 2.1 of the Civil Code of the Russian Federation may be a participant of relations regulated by the corresponding provisions of the Civil Code of the Russian Federation. It should be noted that the digital service "Common portal of government and municipal services (functions)" allows you to submit the documents for the registration of a legal entity without visiting the relevant registration body.

The emergence of scientific research dealing with this type of legal entity as a public organization of territorial public self-government and the introduction of their results into legislative use connected with the legal status of territorial public self-government is not covered in this article. The establishment of a body of territorial public self-government in accordance with the existing power and authority, satisfying the legitimate interests of citizens living in the territory of the body of territorial public self-government, can be a party to civil law relations under construction contracts, leases, provision of services (works), supply of goods, etc., concluded with other participants of civil law transactions [14].

The first aspect of civil law activity of territorial public self-government can be connected with the existence of the need to enter into the legal relationships mentioned above, what is impossible without the registration of a legal entity. The second aspect of the civil legal activity of territorial public self-government encompasses the legal relations arising because of this activity. The third aspect of the activity under analysis is private-law properties of the content of legal relations arising from the work of bodies of territorial public selfgovernment. Let us classify the mentioned aspects as: 1) organizational elements; 2) subject-object elements; 3) behavioral elements.

The first aspect of the activity under analysis of a body of territorial public self-government is characterized by the emergence of legal personality and it is associated with the moment of registration of the specified legal entity and with the opportunity of participation in civil legal relations and with the ability of being a subject of legal relations regulated by civil legislation.

The second aspect of the civil legal activity of the bodies of territorial public self-government is characterized by the structure of the legal relationship under consideration, which includes: subjects (bodies of territorial public self-government and business entities); objects (material goods (property, things, results of work and rendering of services)), through which the social and everyday needs of citizens living in the territory of the TPSG are satisfied); rules of law (provisions of the Civil Code of the Russian Federation governing the relations in which these entities enter).

The third aspect is characterized by the ability of the body of territorial public self-government to acquire the rights and obligations fixed in civil law and bear legal responsibility for their implementation in civil law relations. The author of this article, earlier, came to the conclusion that "the measure of possible and the measure of the necessary behavior of establishment of territorial public self-government depend on the specific civil law contract, to which the body of territorial public selfgovernemnt is a party, and they are determined by the subject matter and other essential terms of the contract" [14].

The structure of territorial self-government (its authorized persons), prior to the emergence of contractual relations, has the right to exercise care and caution when choosing a reliable counterparty (supplier of goods, service provider, etc.). The information about goods or services can be found on the Internet at the corresponding websites of manufacturers or service providers, etc.

You can find out the degree of conscientiousness of a potential counterparty on the information resource "List of arbitration cases" by means of the search for information on the participation of a specific legal entity or individual entrepreneur as a defendant in legal suits held by commercial courts of the constituent entities of the Russian Federation. The claims proving the repeated non-fulfillment of contractual obligations will be the reason for the refusal to such a counterparty. An additional source of information may be the "Databank of enforcement proceedings" service, with which you can check the availability of enforcement proceedings in the Federal Bailiff Service of a potential counterparty, i.e. an individual entrepreneur or legal entity.

In accordance with Paragraph 1 of Article 7 of the Federal Law issued on August 8, 2001 No. 129-FZ "On State Registration of Legal Entities and Individual Entrepreneurs", a service has been developed ("Provision of Information from the Unified State Register of Legal Entities / Unified State Register of Individual Entrepreneurs"), which provides the information about a specific legal entity or an individual entrepreneur for free. On the basis of the provided information, it is possible to establish the powers of persons planning to sign a civil contract with a structure of territorial selfgovernment.

Modern digital technologies make it possible to negotiate with potential contractors about contracts by means of various video conference programs, exchange 
of financial and economic documents via the e-mail, sign payment and other documents with an electronic signature.

If, in the process of contractual relations, unresolved claims arise, for example, the structure of territorial selfgovernment has claims against the service provider under the contract, then you can submit a claim and documents electronically to the Arbitration Court by means of "My Arbitrator" system, and you can participate in the court session via a video conference.

The entire set of modern digital services contributes to an effective work of a territorial self-government organization. At the same time, there is an unresolved problem associated with the current sanitary and epidemiological situation caused by the threat of the spread of a new corona virus infection (Covid-19). So, according to Part 4 of Article 27 of Federal Law No. 131-FZ issued on October 6, 2003, bodies of territorial self-government are elected at meetings or conferences of citizens living in the respective territory. In accordance with Paragraphs 5 and 6 of Part 7 of Article 27 of the Law mentioned above, at conferences and meetings of citizens, the income and expenditure estimates of structures of territorial self-government are approved, statements of territorial self-government bodies are presented and approved, and other issues of activities of territorial public self-government are studied. The provisions on territorial self-government and other types of regulatory legal acts (for example, the Charter of a municipality) regulating the procedure for the establishment, functioning and termination of work of territorial self-government) in municipalities of various constituent entities of the Russian Federation provides for a procedure according to which the territorial self-government body is authorized to act in the interests of citizens during a certain period. For example, in accordance with Article 11 Paragraph 3.2 of the Regulations on Territorial Public Self-Government in Volgograd (approved by the decision of the Volgograd City Duma of February 21, 2007 N 41/1010), the Charter of a territorial self-government body establishes: procedure for the formation, termination of powers, rights and obligations, term of office of territorial public self-government bodies. In practice, in most cases, in the territorial self-government organization such as the Council of territorial self-government is elected and then functions. It consists of three or more people, headed by the Chairman of territorial self-government body elected from the members of territorial self-government Council. The Chairman of the Council acts without a power of attorney on behalf of the structure of territorial selfgovernment, represents it in its relations with the population, judicial and other bodies, organizations of all forms of ownership, signs financial and other documents. As a rule, the members of the Council and the Chairman of the territorial self-government are elected for a term of 4 years.

After the expiration of the specified period or when need arises, there is a necessity to hold a meeting (conference) of citizens living in the area of territorial self-government for the re-election of persons mentioned above and to study the reports on the activity of bodies of territorial self-government.

In Volgograd Region, in accordance with Clause 18 of the Decree of the Governor of Volgograd Region issued on March 15, 2020 No. 179 "On the introduction of a high readiness regime for the functioning of command and control bodies, forces and means of the territorial subsystem of Volgograd Region of the unified state system for the prevention and elimination of emergencies" (amended by October 30, 2020), heads of public organizations and associations operating in Volgograd Region were advised to freeze mass events with the presence of citizens, for the exception of activities carried out in agreement with the operation headquarters implementing measures which help to prevent the emergence and spread of the new coronavirus infection (COVID -19) in Volgograd region.

According to clause 3.3 of this Resolution, citizens who have reached the age of 65 are recommended to self isolate at the place of residence. It is not difficult to assume that even upon receipt of an agreement from the operational headquarters for such a mass event as a meeting (conference) of citizens living in the territory of territorial self-government, the citizens themselves, due to the risk of the spread of coronavirus infection, may not ensure their attendance, depriving the meeting (conference) the required quorum for its eligibility. Without the procedure for the reelection of the Council and the chairman of the body of territorial selfgovernment, there is a danger of freezing the activities of a body of territorial self-government due to the absence of a person authorized to sign civil contracts and take other necessary actions. It seems that the solution of this problem can be the development of a digital service as part of the national program "Digital Economy of the Russian Federation", which allows holding meetings (conferences) of citizens remotely, via video conferencing, and appropriate amendments to the current legislation.

For example, the Government of the Russian Federation has developed a draft of the Federal Law "On Amendments to the Federal Law "On Joint Stock Companies" in terms of creation the opportunity for holding general meetings of shareholders in the form of a video conference for the discussion of issues on the agenda and taking decisions on issues, put to a vote, using information and communication technologies without specifying the venue". In connection with the mentioned above, the author suggests amending the Federal Law issued on October 6, 2003 N 131-FZ and supplementing Clause 2 of Article 27 of the Law with a new paragraph as follows: "Meetings and conferences of citizens can be held by joint remote presence using information and communication technologies without specifying the venue". The suggested solution will help not only the existing organizations of territorial selfgovernment, but also will simplify the procedure of the establishment of new bodies of territorial public selfgovernment.

\section{Research Methods}


The methodological basis of the research is dialectical method of cognition, method of analysis, synthesis and other methods of scientific knowledge.

\section{Findings}

Summing up the article, the following conclusions can be drawn:

Firstly, territorial public self-government is an essential element of constitutional and municipal law, but the analysis shows that the activities of bodies of territorial self-government have distinct civil law aspects.

Secondly, the essential characteristics of the organization of territorial self-government include legal personality (the ability to be a subject of civil law) and the content of a legal relationship with the participation of the subject under analysis.

Thirdly, the legal relations that develop during the work of a body of territorial public self-government are subject to regulation by civil legislation and intermediate the participation of the territorial self-government structure in civil transactions.

Fourth, the set of the identified civil law aspects of the activity of territorial public self-government proves that the activity of the structures of territorial public selfgovernment belong to civil law.

Fifth, the activities of the structures of territorial public self-government at all stages of its functioning can be carried out most efficiently thanks to the "tools" of digitalization of the economy. The problems of the implementation of territorial public self-government in the current difficult epidemiological conditions require sophisticated measures.

\section{Conclusion}

Thus, on the basis of the results obtained, it can be argued reasonably that the signs of such a legal phenomenon as the activity of an organization of territorial public self-government held in relation to the objects of civil law regulation, prove its private legal nature. It is suggested to solve the problem of obstacles in the exercise of territorial public self-government by citizens by means of the amendments to Federal Law No. 131-FZ issued on October 6, 2003.

\section{References}

1. Presidium of the Council under the President of the Russian Federation for Strategic Development and National Projects, Passport of the national project "National Program" Digital Economy of the Russian Federation" (Minutes of 04.06.2019 N 7) (2019), URL: http://base.garant.ru/72296050/ (date of access 12.01.2020)

2. I. M. Konobeevskaya, Bulletin of Saratov University. New Series. Series Economics. Management. Law 19 (3), 330-334 (2019) https://doi.org/ 330-334

10.18500/1994-2540-2019-19-3-

S.G. Eremeev, A.B. Mayorov, E.N. Minchenkov, Theory and history of state and law 4 (54), 9-17 (2018)

4. E.G. Komissarova, Perm University Bulletin 2 (16), 23-29 (2012)

5. S.V. Malyugin, Russian legal journal 3 (108), 4658 (2016)

6. A.V. Fedotov, Territorial public self-government: constitutional foundations, practice of legal regulation (Dissertation of Candidate of Legal Sciences) (Moscow State Social University, Moscow, 2004)

7. E.V. Razdyakonova, Modern law 7, 21-24 (2009)

8. A.A. Larichev, Collection of articles based on materials of the IV All-Russian Scientific and Practical Conference (December 7, 2018), 103-109 (Saint-Petersburg Institute, Saint-Petersburg, 2018)

9. O.I. Bazhenova, Local Law 5, 77-102 (2015)

10. O.I. Bazhenova, Local Law 1, 109-110 (2016)

11. E.S. Shugrina, Bulletin of Surgut State University. Issue 1 (7), 104-107 (2015)

12. E.A. Bratseva, State power and local government 12, 50-55 (2019)

13. K.M. Khudoley, D.M. Khudoley, (2017). Electronic supplement to the Russian Law Journal 3, 68-80.

14. N.A. Korovin, Collection of scientific papers of the 3rd International Scientific Conference (May 15, 2020), 103-109 (South Western State University, Kursk, 2020). 